\title{
PELATIHAN PLANK UP-DOWN TERHADAP KEKUATAN OTOT BAHU ATLET PUTRA SHORINJI KEMPO
}

\author{
Anak Agung Ngurah Putra Laksana1 \\ ${ }^{1}$ Fakultas Keguruan dan Ilmu Pendidikan \\ Universitas PGRI Mahadewa \\ Denpasar, Indonesia \\ e-mail: agungputralaksana@gmail.com
}

\begin{abstract}
Abstrak
Kekuatan otot bahu merupakan komponen fisik yang diperlukan dalam olahraga Shorinji Kempo untuk mencapai prestasi, karena kekuatan otot bahu menentukan kualitas dari pukulan, maka diperlukan metode pelatihan tentang kekuatan otot bahu melalui gerakan-gerakan yang lebih efektif. Latihan plank up-down merupakan latihan untuk melatih kekuatan otot bahu, penelitian ini bertujuan untuk membuktikan pelatihan plank up-down dalam meningkatkan kekuatan otot bahu pada atlet putra Shorinji Kempo Singaraja jenis penelitian true experimental dengan rancangan randomized pre test and post test with control group design. Subjek penelitian adalah atlet putra shorinji kempo singaraja yang sebanyak 20 atlet putra dan dibagi dalam dua kelompok, Kelompok Perlakuan dan Kelompok Kontrol. Kelompok Perlakuan di berikan pelatihan plank up-down 10 repetisi 3 set dan Kelompok Kontrol di berikan pelatihan plank 30 detik 3 set, frekuensi latihan 3 kali dalam seminggu selama 6 minggu. Pengukuran otot bahu menggunakan alat expending dynamometer. Hasil penelitian pada kedua kelompok didapat rerata kekuatan otot bahu sebelum pelatihan plank up-down 10 repetisi 3 set $28,00 \pm 2,00 \mathrm{~kg}$ dan sesudah pelatihan $35,00 \pm 1,30$ $\mathrm{kg}$. Rerata kekuatan otot bahu sebelum pelatihan plank 30 detik 3 set $27,00 \pm 1,85 \mathrm{~kg}$ dan sesudah pelatihan $3231,50 \pm 2,00 \mathrm{~kg}$. Uji beda rerata peningkatan kekuatan otot bahu pada Kelompok Perlakuan dan Kelompok Kontrol menggunakan independent $t$-test pada data post test ke dua kelompok menunjukkan nilai $p=0,001 \quad(p<0,05)$. Disimpulkan bahwa Kelompok Perlakuan dan Kelompok Kontrol sama-sama memberikan efek peningkatan $(p<0,05)$ dan Kelompok Perlakuan lebih meningkatkan kekuatan otot bahu daripada Kelompok Kontrol pada atlet putra Shorinji Kempo Singaraja. Saran dalam penelitian ini diharapkan para pelatih dapat memberikan pelatihan secara tepat dengan prinsip latihan dan metode latihan untuk meningkatkan prestasi atlet.
\end{abstract}

Kata kunci: kekuatan otot bahu, plank up-down, Shorinji Kempo

\begin{abstract}
Shoulder muscle strength is a physical component that is needed in shorinji kempo sports to achieve achievement, because shoulder muscle strength determines the quality of the stroke, it requires training methods on shoulder muscle strength through movements that are more effective. Up-down plank training is an exercise to train shoulder muscle strength, this training aims to prove up-down plank training in increasing shoulder muscle strength in male athletes. control group design. The research subjects were male athletes Shorinji Kempo Singaraja with a total of 20 male athletes and were divided into two groups, the Treatment Group and the Control Group. The Treatment Group was given a plank up-down training of 10 reps 3 sets and the Control Group was given a 30 second set of plank training, exercise frequency 3 times a week for 6 weeks. Shoulder muscle measurement using an expending dynamometer. The results of the study in both groups obtained mean shoulder muscle strength before plank up-down training 10 reps 3 sets of $28.00 \pm 2.00 \mathrm{~kg}$ and after training $35.00 \pm 1.30 \mathrm{~kg}$. Average shoulder muscle strength before plank training 30 seconds 3 sets $27.00 \pm 1.85 \mathrm{~kg}$ and after training $3231.50 \pm 2.00$ $\mathrm{kg}$. Mean different test for increasing shoulder muscle strength in the Treatment and Control Groups using independent $t$-test in the post test data of the two groups showed a value of $p=$ 0.001 ( $p<0.05$ ). It was concluded that the Treatment Group and Control Group both had an increased effect $(p<0.05)$ and the Treatment Group increased shoulder muscle strength more than the Control Group in male athletes Shorinji Kempo in Singraja. Suggestions in this study are
\end{abstract}


ISSN 2356-3397 (Print) | ISSN 2597-4505 (Online)

expected to coaches to provide training appropriately with the principles of training and training methods to improve athlete performance.

Keywords: shoulder muscle strength, plank up-down, shorinji kempo

\section{PENDAHULUAN}

Olahraga adalah suatu bentuk aktivitas fisik yang terencana dan terstruktur yang melibatkan gerakan tubuh berulang-ulang dan ditujukan untuk meningkatkan kebugaran jasmani. Kesehatan olahraga adalah upaya meningkatkan kesehatan yang memanfaatkan olahraga untuk meningkatkan derajat kesehatan. Olahraga merupakan sebagian kebutuhan pokok dalam kehidupan sehari-hari karena dapat meningkatkan kebugaran yang diperlukan dalam melakukan aktivitas. Olahraga dapat dimulai sejak usia dini hingga usia lanjut dan dapat dilakukan setiap hari. Proses latihan secara berkelanjutan juga mempengaruhi hasil tendangan mawashi geri yang maksimal, latihan merupakan suatu aktivitas fisik. menurut Harsono dalam James latihan adalah seperangkat kegiatan dalam berlatih yang diatur sedemikian rupa sehingga dapat dilaksanakan oleh siswa pelajar/atlet, baik mengenai jumlah beban latihan maupun intesitas latihanya (James Tangkudung, 2012). Menurut Fox, Bowers dan Foss, latihan adalah suatu program latihan fisik untuk mengembangkan kemampuan seorang atlet dalam menghadapi pertandingan penting (Setyo Budiwanto, 2012). Sedangkan Menurut bompa latihan adalah proses dimana seorang atlet dipersiapkan untuk performa tertinggi (Tudor O. Bompa, 2009). Dengan demikian pengertian latihan adalah sebagai suatu proses kemampuan berolahraga yang didalamnya terdapat materi teori dan praktek, menggunakan metode latihan, dan aturan pelaksanaan dengan pendekatan ilmiah, memakai prinsip pendidikan yang terstruktur dan terencana, sehingga tujuan latihan dapat tercapai sesuai yang diinginkan.

Shorinji Kempo merupakan beladiri yang sangat kompleks dengan teknik-teknik keras goho : memukul, menyerang, menendang memotong dan teknik lunak juho : menunduk, melempar, memutar, menekan, mencekik, membungkuk, dan melipat, yang digabung secara harmonis yang merupakan suatu kesatuan yang tidak dapat dipisahkan (Laksana, 2020). Shorinji Kempo dapat menguatkan jiwa dan raga melalui latihan berbagai teknik dan memperoleh kepercayaan diri tanpa menjadi sombong, memiliki keberanian dan kekuatan untuk bertindak menjadi pribadi yang dapat diandalkan. Dalam Shorinji Kempo terdapat pengertian kekuatan sejati yaitu (1) Bagi setiap orang, hubungan yang baik dengan diri sendiri sangat penting untuk menghargai diri sendiri, diperlukan keberanian untuk mengatakan secara langsung apa yang tidak disukai atau melihat sesuatu yang tidak benar, dan juga, membutuhkan kekuatan untuk menghindari hal-hal seperti itu. (2) Ketika kita mengatakan kekuatan sejati, kita tidak mengartikan kekuatan sebagai mengalahkan lawan, melainkan kekuatan yang ditemukan dalam pribadi, dapat diandalkan dan keberanian untuk menjalani hidup, (3) dengan menerapkan Shorinji Kempo, kita akan mendapatkan kepercayaan diri dan berbagi kebahagiaan, bukan hanya untuk diri kita sendiri tetapi juga untuk orang lain di sekitar kita, serta untuk membantu satu sama lain, mengembangkan kemampuan untuk melawan ketidakadilan di masyarakat. Itu benar-benar kekuatan sejati di Shorinji Kempo (Laksana, 2019). 
Seseorang yang mampu melakukan gerak keterampilan dengan baik dikatakan terampil. Orang yang terampil mampu melakukan tugas gerak secara efisien dan efektif. Dikatakan efisien adalah apa bila pelaksanaan gerak tidak banyak mengeluarkan tenaga tanpa membuang tenanga yang seharusnya tidak dikeluarkan. Sedangkan dikatakan efektif apabila pelaksanaan gerak sesuai dengan apa yang dikehendaki atau sesuai dengan tujuannya (Widiastuti, 2011). Keterampilan gerak adalah kemampuan untuk melakukan gerak secara efisien dan efektif. Keterampialan gerak merupakan perwujudan dari kualitas koordinasi dan kontrol atas bagian bagian tubuh yang terlibat dalam gerakan. Makian kompleks pola gerak yang harus dilakukan, makin kompleks juga koordinasi dan kontrol tubuh yang harus dilakukan Keterampilan gerak diperoleh melalui proses belajar yaitu dengan cara memahami gerak dan melakukan gerakan berulang ulang yang disertai dengan kesadaran berpikir akan benar atau tidaknya gerakan yang dilakukan. Keterampilan gerak dapat dikaji berdasarkan karakteristik dan kekudian diklasifikasikan berdasarkan kesamaan karaskteristik pada pola-pola tertentu. Dengan pengklasifikasian pelatih olahraga bisa menggunakannya untuk mempermudah menganalisis gerak yang diberikan kepada atlet. (Laksana, 2020).

Berdasarkan pengamatan di lapangan prestasi atlet di Singaraja dalam mengikuti PORSENIJAR dan Walikota CUP masih belum menunjukan hasil yang optimal. Dilihat dari pertandingan yang diikuti, saat memberikan serangan kepada lawan dengan teknik pukulan terlihat sangat lemah dan kurang optimal sehingga lawan sangat mudah untuk membalas serangan yang membuat point lawan terus bertambah, sedangkan peluang terbesar untuk memperoleh point adalah melalui teknik pukulan. Hal ini kemungkinan disebabkan atlet di dojo singaraja kurang mendapatkan latihan untuk meningkatkan kekuatan otot bahu, latihan disana cenderung lebih melatih kekuatan otot lengan. Kondisi fisik merupakan aspek utama yang harus dipenuhi dalam mencapai prestasi yang optimal (Supriyoko \& Mahardika, 2018). Kondisi fisik menunjang teknik, taktik, dan mental (Hardiono, 2019). kekuatan adalah kemampuan otot untuk mengatasi hambatan dalam kurun waktu tertentu (Mylsidayu 2014), sedangkan Johansyah (2013) mengartikan bahwa kekuatan adalah kemampuan sistem neuromuskuler untuk menghasilkan gaya atau kekuatan untuk melawan tahanan luar, Penulis lain Widiastuti (2015) menyebutkan kekuatan adalah kemampuan otot untuk melakukan suatu kontraksi secara maksimal terhadap hambatan atau beban. Gordon (2009) membagi tipe kekuatan menjadi 5 tipe. Pembagian kekuatan tersebut didasarkan pada hubungan kekuatan, kecepatan, percepatan serta hubungan panjang/ketegangan otot, sehingga dapat dibuat tingkatan yang semuanya memiliki implikasi untuk atlet. Klasifikasi tersebut adalah sebagai berikut: (1) Base strength, membentuk pondasi untuk semua tingkatan lain dari pengembangan kekuatan. Base strength merupakan faktor kunci yang harus dimiliki oleh semua atlet pemula dan untuk semua jenis atlet yang diproyeksikan ke tahap persiapan dari program tahunan; (2) Action strength, kekuatan tindakan dikaitkan dengan spesifikasi dari cabang olahraga saat atlet bergerak; (3) Maximum strength, kekuatan maksimum sering disebut sebagai satu repetisi maksimal. Terminologi yang digunakan untuk menggambarkan jumlah repetisi maksimal kekuatan yang diproduksi oleh otot-otot yang terlibat selama kontraksi; (4) Muscular endurance, hal ini mencerminkan kemampuan otot untuk mempertahnkan tingkat yang diinginkan untuk jangka waktu yang lama; dan (5) Power adalah produk dari kekuatan otot dan kecepatan kontraksi. Menurut Chan (2012) menjelaskan strength atau kekuatan, yaitu suatu 
kemampuan kondisi fisik manusia yang diperlukan dalam peningkatan prestasi belajar gerak. Hal ini merupakan komponen yang paling mendasar dan sangat penting dalam olahraga, mengingat kekuatan merupakan daya penggerak setiap aktivitas fisik yang berperan untuk mencegah cedera dan merupakan komponen dasar bagi komponen kondisi fisik lainnya. Kekuatan otot ini sangat dibutuhkan dalam melakukan gerakangerakan seperti: menarik, melempar, menolak, mendorong dan mengangkat. Gerakangerakan tersebut timbul akibat adanya kontraksi otot memanjang, memendek, menjauhi, mendekati bagian tubuh, dan gerakan memutar ke seluruh arah dalam rentang sudut $360^{\circ}$.

Kekuatan otot bahu merupakan salah satu faktor yang menentukan kualitas dari pukulan, dalam suatu teknik pukulan bagian tubuh yang digunakan memukul adalah tangan, namun yang menjadikan pukulan tersebut baik adalah adanya koordinasi antara otot lengan dan otot bahu. Kurangnya koordinasi dari otot tersebut mengakibatkan pukulan gagal atau kurang keras bahkan kemungkinan terjadi cedera. Otot bahu berfungsi mendorong lengan yang melakukan pukulan, juga bertugas untuk menarik kembali secara cepat lengan yang melakukan pukulan. Dapat dikatakan kekuatan otot bahu merupakan komponen yang menentukan untuk mencapai potensi optimal, maka diperlukan pelatihan tentang meningkatkan kekuatan otot bahu melalui gerakan-gerakan yang lebih efektif. Ada beberapa cara untuk meningkatkan kekuatan otot-otot terutama pada otot bahu, seperti angkat gantung (pull up), melempar bola, push up, plank dan mengangkat barbell (Dismore, 2011). Latihan plank up-down adalah latihan isometric yang melatih kekuatan yang melibatkan seluruh otot dalam mempertahankan posisi tubuh yang sama seperti push up selama mungkin. Menurut Sukadiyanto (2011: 91-92), bahwa kontraksi isometric adalah meningkatnya ketegangan otot pada saat memanjang, sehingga panjang otot dalam keadaan tetap atau tidak berubah. Latihan isometric merupakan bentuk latihan kekuatan yang populer di tahun 1960-an. Latihan kekuatan dengan cara isometric lebih efektif untuk melatih kekuatan maksimal, hypertrophy otot, dan program penyembuhan cedera pada otot. Hasil pelatihan plank up-down yang dilaksanakan secara sistematis kontinyu, berkesinambungan dan teratur dalam beberapa repetisi dan beberapa set akan berpengaruh terhadap kekuatan, daya tahan, kelentukan koordinasi dan otot bahu. Semakin kuat dan semakin lama seseorang dapat melakukan gerakan plank up-down semakin baik pula kekuatan otot-otot bahunya untuk meningkatkan kondisi fisik.

Gerakan plank up-down yaitu Posisi tubuh pada awalnya sample tidur tengkurap dengan tangan disisi kanan kiri badan dengan kedua siku menempel di lantai/matras. Kemudian salah satu tangan didorong ke atas dengan kekuatan otot tangan dan lengan yang disusul oleh tangan berikutnya secara bergiliran. Posisi kaki dan badan tetap lurus atau tegap, setelah itu badan di turunkan dengan tetap menjaga kondisi badan dan kaki tetap lurus.Gerakan tangan pada pelatihan plank up-down kaki siku dan tangan berada pada permukaan lantai atau tanah, tangan kanan dan tangan kiri di buka selebar bahu lalu di mulai bergerak keatas dan kebawah dengan menggunakan kekuatan otot bahu secara bergiliran dengan salah satu tangan mendorong ke atas terlebih dahulu kemudian di susul oleh tangan berikutnya. Bentuk latihan plank up-down membuat otot berkontraksi dengan sangat kuat yang merupakan respon dari pembebanan statis dari otot-otot yang terlibat. Adanya pembebanan tersebut mengakibatkan hypertrophy otot, efek yang timbul dari hypertrophy otot akan mengakibatkan terjadinya peningkatan 
kekuatan otot. Hypertrophy otot tergantung dari latihan yang dilakukan. Dalam kekuatan, yang akan menjadi besar adalah otot lambat, hypertrophy yang disebabkan karena latihan, biasanya disertai perubahan-perubahan, sebagai berikut: (1) peningkatan jumlah myofibril, (2) peningkatan jumlah filamen aktin, (3) peningkatan jumlah miosin, (4) peningkatan jumlah sarkoplasma, serta jaringan penunjang lainnya (Wedi dan Umar, 2019). Pelatihan diberikan kepada atlet putra shorinji kempo di singaraja yang dibagi menjadi dua kelompok, yaitu Kelompok Perlakuan diberikan perlakukan pelatihan plank up-down 10 repetisi 3 set dan Kelompok Kontrol diberikan pelatihan plank 30 detik 3 set. Ke dua kelompok diberikan pelatihan dengan frekuensi 3 kali seminggu selama 6 minggu, beban pelatihan yang digunakan adalah berat badan sendiri, dan intensitas pelatihan disesuaikan dengan kemampuan maksimal atlet.

\section{METODE}

Penelitian dilakukan di dojo singaraja, pengambilan data dilakukan pada bulan Mei 2020 s/d Juni 2020, Latihan dilakukan selama 6 minggu dengan frekuensi 3 kali latihan dalam seminggu (Senin, Rabu dan Jumat) pukul 16:00 s/d 18:00 WITA. Jenis penelitian true eksperimental dengan rancangan randomized pretest and posttest with control group design. Penelitian dilakukan untuk mengetahui pelatihan plank up-down dalam mengikatkan kekuatan otot bahu pada atlet Shorinji kempo Singaraja. Pengukuran kekuatan otot bahu menggunakan expanding dynamometer.

Sampel diambil menggunakan random sampling menggunakan rumus Pocock yang berjumlah 16 orang, sampel pada penelitian ini di dibagi ke dalam dua kelompok berdasarkan kriteria eksklusi dan inklusi. Kelompok Perlakukan latihan plank up-down 10 repetisi 3 set, Kelompok Kontrol latihan plank 30 detik 3 set. Pelatihan di lakukan dengan frekuensi 3 kali latihan selama 6 minggu. Penelitian ini dilakukan dengan memberikan penjelasan secara tertulis dan lisan mengenai tujuan penelitian, hak responden, manfaat penelitian. Selanjutnya dilakukan pretest guna mengetahui kekuatan otot bahu, Kelompok Perlakukan latihan plank up-down 10 repetisi 3 set, Kelompok Kontrol latihan plank 30 detik 3 set selama 6 minggu. Setelah melakukan pelatihan masing-masing kelompok melakukan post test.

\section{HASIL DAN PEMBAHASAN}

Berdasarkan dari hasil pengujian Normalitas data (Shapiro-walk test) kekuatan otot bahu data sebelum dan sesudah dari pelatihan Kelompok Perlakuan dan Kelompok Kontrol menunjukkan hasil nilai $p$ ke dua kelompok di atas 0,05 atau $p$ lebih besar dari $(p<0,05)$, sehingga data penelitian berdistribusi normal. Berdasarkan dari hasil uji Homogenitas data menggunakan Levenes Test menunjukkan hasil nilai $p$ ke dua Kelompok di atas 0,05 atau $p$ lebih besar dari $(p<0,05)$ sehingga data penelitian bersifat homogen. Uji Hipotesis menggunakan paired t test untuk mengetahui perbedaan dari efek latihan plank up-down dan plank sebelum dan sesudah pelatihan terhadap peningkatan kekuatan otot bahu, dan independent $t$ test untuk mengetahui perbedaan efek kedua kelompok sesudah pelatihan plank up-down dan plank terhadap peningkatan kekuatan otot bahu. Karakter dari subjek penelitian terdiri dari umur, tinggi badan dan berat badan dapat di lihat pada Tabel 1 . 
ISSN 2356-3397 (Print) | ISSN 2597-4505 (Online)

Tabel 1. Distribusi Data Subjek Berdasarkan Umur, Tinggi Badan, Berat Badan Ke Dua Kelompok

\begin{tabular}{lll}
\hline Karakteristik Subjek & $\begin{array}{l}\text { Kelompok } \\
\text { Perlakuan } \\
\text { (Rerata } \pm \text { SB) }\end{array}$ & $\begin{array}{l}\text { Kelompok Kontrol } \\
\text { (Rerata } \pm \text { SB) }\end{array}$ \\
\hline Umur (th) & $19,50 \pm 1,19$ & $19,38 \pm 1,68$ \\
Tinggi Badan $(\mathrm{cm})$ & $168,38 \pm 1,76$ & $167,38 \pm 2,38$ \\
Berat Badan $(\mathrm{kg})$ & $65,88 \pm 3,87$ & $63,75 \pm 4,46$ \\
\hline
\end{tabular}

Tabel 1 menunjukkan bahwa karakteristik sampel pada kelompok perlakuan dari segi umur dengan rerata 19,50 $\pm 1,19$ tahun, rerata tinggi badan 168,38 $\pm 1,76 \mathrm{~cm}$, rerata berat badan $65,88 \pm 3,87 \mathrm{~kg}$. Karakteristik sampel penelitian pada Kelompok Kontrol dari segi umur dengan rerata 19,38 $\pm 1,68$ tahun, rerata tinggi badan $167,38 \pm 2,38 \mathrm{~cm}$, rerata berat badan $63,75 \pm 4,46 \mathrm{~kg}$. Dari data tersebut, karakteristik kedua kelompok sampel penelitian berada dalam kondisi yang sama, sehingga variabel umur, tinggi badan, dan berat badan tidak berpengaruh terhadap hasil penelitian ini.

Data sebelum dan sesudah pelatihan berdasarkan uji Normalitas dan homogenitas terhadap ke dua kelompok bisa di lihat pada Tabel 2.

Tabel 2. Uji Normalitas dan Homogenitas Kekuatan Otot Bahu Ke dua Kelompok.

\begin{tabular}{cccc}
\hline \multirow{2}{*}{$\begin{array}{c}\text { Pengukuran } \\
\text { Kekuatan Otot } \\
\text { Bahu }\end{array}$} & \multicolumn{2}{c}{$\begin{array}{c}\text { Uji Normalitas } \\
\text { (Saphiro Wilk-Test) }\end{array}$} & $\begin{array}{c}\text { Uji Homogenitas } \\
\text { (Levene-Test) }\end{array}$ \\
\cline { 2 - 4 } & $\begin{array}{c}\text { Kelompok } \\
\text { Perlakuan }\end{array}$ & $\begin{array}{c}\text { Kelompok } \\
\text { Kontrol }\end{array}$ & Nilai $\mathrm{p}$ \\
\hline Nilai $\mathrm{p}$ & Nilai $\mathrm{p}$ & \\
\hline Tes Awal & 0,223 & 0,424 & 0,775 \\
Tes Akhir & 0,857 & 0,600 & 0,637 \\
\hline
\end{tabular}

Berdasarkan Tabel 2 hasil uji normalitas data (Shapiro-walk test) pada kekuatan Otot Bahu sebelum dan sesudah pelatihan pada Kelompok Perlakuan dan Kelompok Kontrol menunjukan bahwa data pada kedua kelompok menunjukan nilai $p$ lebih besar dari $0,05(p>0,05)$, sehingga dinyatakan data berdistribusi normal. Hasil uji homogenitas (Levene Test) menunjukkan bahwa data pada kedua kelompok berdasarkan hasil pengukuran kekuatan otot bahu bersifat homogen karena nilai $p$ lebih besar dari 0,05 $(p>0,05)$, sehingga data dapat diuji dengan menggunakan uji parametrik untuk melihat adanya peningkatan atau penurunan hasil pada variabel penelitian.

\section{Hasil Uji Beda Kekuatan Otot Bahu Sebelum dan Sesudah Pelatihan Pada Kelompok Penelitian}

Uji rerata perbedaan sebelum dan sesudah pelatihan kekuatan otot bahu dapat dilihat pada Tabel 3. 
ISSN 2356-3397 (Print) | ISSN 2597-4505 (Online)

Tabel 3. Uji Rerata Perbedaan Peningkatan Kekuatan Bahu Sebelum dan Sesudah Pelatihan

\begin{tabular}{|c|c|c|c|c|c|}
\hline $\begin{array}{c}\text { Pengukuran } \\
\text { Kekuatan } \\
\text { Otot Bahu }\end{array}$ & $\begin{array}{c}\text { Sebelum } \\
\text { (Rerata } \pm S B)\end{array}$ & $\begin{array}{c}\text { Sesudah } \\
\text { (Rerata } \pm S B)\end{array}$ & $\mathbf{T}$ & & $\mathbf{P}$ \\
\hline $\begin{array}{l}\text { Kelompok } \\
\text { Perlakuan }\end{array}$ & $28,00 \pm 2,00$ & $35,00 \pm 1,30$ & $-12,347$ & 0,000 & \\
\hline $\begin{array}{l}\text { Kelompok } \\
\text { Kontrol }\end{array}$ & $27,00 \pm 1,85$ & $31,50 \pm 2,00$ & $-11,906$ & 0,000 & \\
\hline
\end{tabular}

Berdasarkan Tabel 3 menunjukkan bahwa perbedaan rerata kekuatan otot bahu pada Kelompok Perlakuan sebelum dan sesudah pelatihan berdasarkan pengukuran menggunakan alat expanding dynamometer menunjukan nilai $p$ lebih kecil dari 0,05 $(p<0,05)$. Sehingga nilai tersebut menyatakan ada peningkatan yang bermakna pada kekuatan otot bahu Kelompok Perlakuan. Pada Kelompok Kontrol sebelum dan sesudah pelatihan berdasarkan pengukuran menggunakan alat expanding dynamometer menunjukan nilai $p$ lebih kecil dari $0,05(p<0,05)$. Sehingga nilai tersebut menyatakan ada peningkatan yang bermakna pada kekuatan otot bahu Kelompok Kontrol.Dari hasil uji hipotesis menunjukan bahwa rerata data kekuatan sebelum dan sesudah pelatihan pada masing-masing kelompok terdapat peningkatan bermakna $(p<0,05)$. Dengan demikian dapat dikatakan bahwa kedua kelompok pelatihan memiliki pengaruh pelatihan dalam meningkatkan kekuatan otot bahu. Kelompok Perlakuan lebih meningkatkan kekuatan otot bahu dari pada Kelompok Kontrol, ini dapat dilihat dari hasil peningkatan Kelompok Perlakuan yang lebih bermakna yaitu dari $28,00 \mathrm{~kg}$ menjadi $35,00 \mathrm{~kg}$ sedangkan Kelompok Kontrol yaitu dari $27,00 \mathrm{~kg}$ menjadi $31,50 \mathrm{~kg}$.

\section{Uji Beda Kekuatan Otot Bahu Sesudah Pelatihan Antar Kelompok Penelitian}

Uji beda efek antar kelompok dalam menentukan hasil akhir Kekuatan otot bahu dapat di lihat pada Tabel 4.

Tabel 4. Uji Perbedaan Efek Antar Kelompok Dalam Menentukan Hasil Akhir Kekuatan Otot Bahu

\begin{tabular}{lcccc}
\hline $\begin{array}{l}\text { Pengukuran } \\
\text { Kekuatan } \\
\text { Otot Bahu }\end{array}$ & $\begin{array}{c}\text { Sebelum } \\
\text { (Rerata } \pm \text { SB) }\end{array}$ & $\begin{array}{c}\text { Sesudah } \\
\text { (Rerata } \pm S B)\end{array}$ & T & P \\
\hline $\begin{array}{l}\text { Kelompok } \\
\text { Perlakuan }\end{array}$ & $28,00 \pm 2,00$ & $27,00 \pm 1,85$ & 1,038 & 0,317 \\
$\begin{array}{l}\text { Kelompok } \\
\text { Kontrol }\end{array}$ & $35,00 \pm 1,30$ & $31,50 \pm 2,00$ & 4,141 & 0,001 \\
\hline
\end{tabular}

Berdasarkan Tabel 4 bahwa didapatkan beda rerata hasil pengukuran sesudah pelatihan pada Kelompok Perlakuan dan Kelompok Kontrol hasil nilai $p$ lebih kecil dari $0,05(p<0,05)$. Hal ini menunjukan bahwa ada perbedaan yang bermakna dari hasil pengukuran sesudah mendapatkan pelatihan Plank Up-Down 10 repetisi 3 set dan Pelatihan Plank 30 detik 3 set. Hasil ini menunjukkan ada perbedaan yang bermakna kekuatan otot bahu sesudah pelatihan antara ke dua kelompok penelitian. Dari hasil temuan dilapangan bahwa pelatihan plank up-down dengan 10 repetisi 3 set terhadap kekuatan otot bahu atlet putra shorinji kempo terdapat perbedaan yang bermakna antara hasil pre test sebesar $28,00 \mathrm{~kg}$ dan post test sebesar $35,00 \mathrm{~kg}$, yang menunjukkan hasil bahwa pelatihan plank up-down 10 repetisi 3 set meningkatkan kekuatan otot bahu atlet Shorinji Kempo Singaraja. Hal ini juga diperkuat dengan Penelitian Januarshah Zulvikar dengan judul pengaruh latihan core stability statis (plank dan side Plank) dan 
core stability dinamis (side lying hip Abduction dan oblique crunch) terhadap keseimbangan, dengan memperoleh hasil penelitian Terdapat perbedaan pengaruh yang signifikan antara latihan plank, side plank, side lying hip abduction, dan oblique crunch terhadap keseimbangan. (Januarshah Zulvikar, 2016)

\section{SIMPULAN DAN SARAN Simpulan}

Berdasarkan hasil analisis data maka dapat disimpulkan bahwa pelatihan plank up-down 10 repetisi 3 set terhadap kekuatan otot bahu atlet putra Shorinji Kempo Singaraja. Ada perbedaan yang bermakna antara hasil pre-test sebesar $28,00 \mathrm{~kg}$ dan post-test sebesar $35,00 \mathrm{~kg}$, yang menunjukkan hasil bahwa pelatihan plank up-down 10 repetisi 3 set meningkatkan kekuatan otot bahu atlet Shorinji Kempo Singaraja.

\section{Saran}

1. Bagi Siswa Diharapkan informasi yang diperoleh melalui penelitian ini bermanfaat bagi bahan perbandingan dan dapat memberikan pemikiran dan pengetahuan berkaitan dengan pelatihan kekuatan pukulan pada saat berhadapan dengan lawan dimana pada pengaruh pelatihan plank up-down 10 repetisi 3 set meningkatkan kekuatan otot bahu atlet putra Shorinji Kempo Singaraja.

2. Bagi para guru olahraga dan pelatih penelitian ini dapat digunakan sebagai acuan dalam melaksanakan pelatihan kekuatan pukulan dengan adanya alat sederhana dan mudah penggunaannya seperti samsak, dan pelatihan plank up-down dan sejenisnya dapat berguna atau bermanfaat bagi kemajuan prestasi siswa maupun atlet shorinji kempo itu sendiri.

\section{DAFTAR PUSTAKA}

Budiwanto, S. (2012). Metodologi Latihan Olahraga. Malang: Universinas Negeri Malang.

Bompa, T. O., \& Haff, G11. G. (2009). Periodezation Theory and Methodology of Training. New York: Human Kinetics.

Chan, F. (2012). Strength Training (Latihan Kekuatan). Jurnal Cerdas Sifa, 1(1).

Chairad, Muhammad.2014 Sejarah Dan Perkembangan Beladiri Tarung Derajat. Jurnal IImu Keolahragaan. 13 (2): 29-37

Dismore, Harriet dan Bailey, Richard. 2011. Fun and enjoyment in physical education: young people's attitudes .ISSN 0267-1522 print/ISSN 1470-1146 online. (c) 2011 Taylor \& Francis.

Gordon, D. (2009). Coaching Science. Retrieved from https://books.google.co.id/books?id=|32hvhkual4C\&pg=PT4\&lpg=PT4\&dq=Co aching+Science + (Cornwall:+Learning+Matters + Ltd, $+2009 \&$ source $=$ bl\&ots $=O v$ 3wCAT04m\&sig=ACfU3U2vm1bUCkqzvgX5T21iTg2jZc1kfQ\&hl=id\&sa=X\&ve $\mathrm{d}=2$ ahUKEwjpMbcprPiAhWx73MBHcPsBVAQ6AEwAHoECAgQAQ\#v=onep.

Hardiono, Bayu. Pengaruh kekuatan otot dominan dan percaya diri terhadap hasil panjatan atlet panjat tebing. Jurnal SPORTIF : Jurnal Penelitian Pembelajaran. Volume 5 Nomor 1 Tahun 2019.

Johansyah. 2013. Penyusunan Program Latihan. Raja Grafindo. Jakarta 
Laksana, Anak Agung Ngurah Putra. Pengaruh metode pelatihan circuit training terhadap peningkatan kelincahan atlet shorinji kempo unit kegiatan mahasiswa ikip pgri bali. Jurnal Jurnal Pendidikan Kesehatan Rekreasi Vol. 6, No. 1, 86-93

Laksana, Anak. Agung. Ngurah Putra. The Effect of Bench Press Exercise on the Pushing Strength of the Arm Muscles toward Shorinji Kempo Athletes. Prosiding ICOPESH Ke-1, Tahun 2019 ISBN 978-623-7482-42-0.

Laksana, Anak. Agung. Ngurah Putra. Implementasi model latihan modifikasi gerak untuk meningkatkan tendangan mawashi geri shorinji kempo. JSPEED Vol 3.NO. 101 November 2020.

Mylsidayu. 2014. Ilmu Kepelatihan Dasar. Jakarta : Alfabeta

Tangkudung, J. \& Wahyuningtyas, P. (2012). Kepelatihan Olahraga. Jakarta: Cerdas Jaya.

Pocock, S. J. 2008. Clinical Trial A Practical Approach. New York: A Willey Medical Publication.

Sukadiyanto, \& Muluk, D. 2011. Pengantar Teori Dan Metodologi Melatih Fisik. Bandung: Lubuk Agung.

Supriyoko, A., \& Mahardika, W. (2018). Kondisi Fisik Atlet Anggar Kota Surakarta. Jurnal SPORTIF : Jurnal Penelitian Pembelajaran, 4(2), 280292.https://doi.org/10.29407/js_unpgri.v4i2.12540.

Wedi, S., Umar, W.W. 2019. Pengaruh Metode Latihan Beban Dengan Gerakan Cepat dan Gerakan Lambat terhadap Peningkatan Hypertrophy Otot Paha. Jurnal Keolahragaan. 5(2): 30-35.

Widiastuti. (2011). Tes dan Pengukuran Olahraga. Jakarta: PT Bumi Timur Jaya.

Zulvikar, Januarshah. Pengaruh latihan core stability statis (plank dan side plank) dan core stability dinamis (side lying hip abduction dan oblique crunch) terhadap keseimbangan. Journal of Physical Education, Health and Sport. 3 (2) (2016). 